Title for subject: Interspecific groups in arthropods

Title for authors: J. Boulay et al.

* Corresponding author: Julien Boulay, CHU Lille, Université Lille 2, EA 7367 - UTML Unité de Taphonomie Médico-Légale, Lille, France.Email : ju.boulay@gmail.com

\title{
MIXED-SPECIES AGGREGATIONS IN ARTHROPODS
}

Julien Boulay ${ }^{1}$, Cindy Aubernon ${ }^{1}$, Graeme D. Ruxton ${ }^{2}$, Valéry Hédouin ${ }^{1}$, Jean-Louis

Deneubourg $^{3}$ and Damien Charabidzé ${ }^{1}$

${ }^{1}$ CHU Lille, Université Lille 2, EA 7367 - UTML - Unité de Taphonomie Médico-Légale, Lille, France

${ }^{2}$ School of Biology, University of St. Andrews, Dyers Brae House, St. Andrews, Fife KY16 9TH

${ }^{3}$ Unit of Social Ecology-CP 231, Université Libre de Bruxelles (ULB), Campus de la Plaine, Boulevard du Triomphe, Building NO-level 5, 1050 Brussels, Belgium

\begin{abstract}
This review offers the first synthesis of the research on mixed-species groupings of arthropods and highlights the behavioural and evolutionary questions raised by such behaviour. Mixed-species groups are commonly found in mammals and birds. Such groups are also observed in a large range of arthropod taxa independent of their level of sociality. Several examples are presented to highlight the mechanisms underlying such groupings, particularly the evidence for phylogenetic proximity between members that promotes cross-
\end{abstract}

This is an Accepted Article that has been peer-reviewed and approved for publication in the Insect Science but has yet to undergo copy-editing and proof correction. Please cite this article as doi: 10.1111/1744-7917.12502.

This article is protected by copyright. All rights reserved. 
species recognition. The advantages offered by such aggregates are described and discussed. These advantages can be attributed to the increase in group size and could be identical to those of non-mixed groupings, but competition-cooperation dynamics might also be involved, and such effects may differ between homo- and heterospecific groups. We discuss three extreme cases of interspecific recognition that are likely involved in mixed-species groups as vectors for cross-species aggregation: tolerance behaviour between two social species, oneway mechanism in which one species is attractive to others and two-way mechanism of mutual attraction. As shown in this review, the study of mixed-species groups offers biologists an interesting way to explore the frontiers of cooperation-competition, including the process of sympatric speciation.

Keywords: collective behaviour; complex system; cross-species recognition; selforganization, sociality

\section{Background}

Over the last 40 years, research into collective behaviour has rapidly expanded. In a milestone book, Krause and Ruxton (2002) reviewed the concepts underlying group-living, and they focused their work on the mechanisms that govern the evolution and maintenance of animal groups in several species. In 2010, Sumpter reviewed how the mechanisms driving group behaviour are intertwined with its functions and concluded that simple rules may generate impressive and complex systems, such as migrating flocks of starlings, schools of fish or wildebeest herds.

This article is protected by copyright. All rights reserved. 
In this context, the study of collective behaviour has mainly focused on intraspecific phenomena (Stamps, 1988; Camazine et al., 2001; Sumpter, 2010; Kivelä et al., 2014), especially in arthropods (see the review by Jeanson et al. [2012]). A Scopus search with 'social' as the keyword (literature published from 2006-2016, performed 13th June 2016) returned 5099 research articles: 53\% were on arthropods. But a large majority of the research on arthropod sociality is focused on eusocial species, especially ants and bees (Wilson, 1971; Krause \& Ruxton, 2002; Sumpter, 2010). They are the topic of $78 \%$ of the scientific publications related to insects (Costa \& Fitzgerald, 2005), likely because they form impressive societies, build complex nest structures and account for more than half of the insect biomass (Wilson \& Hölldobler, 2005). In comparison, the keyword 'mixed-species' found only 168 documents (Scopus searching from 2006-2016). Furthermore, only 8\% were on arthropods while more than half $(58 \%)$ were on vertebrates (see, for example, the reviews by Stensland et al. (2003) and Terborgh (1990) or researches by Farine et al. (2014a, b) and $34 \%$ were on other living organisms (microorganisms, fungi, echinoderms, etc.). 
Some of the best-known cases of mixed-species arthropods societies can be found in eusocial species (Fielde, 1903; Errard, 1994; Vauchot et al., 1996). A striking example involves Harpagoxenus canadensis (a slave-making ant) invading Leptothorax muscorum nests to capture brood and rear them as slave workers (Stuart \& Alloway, 1983). During this process, both species can be found working and living together in the nest, but after some time, $H$. canadensis appropriates the brood of the other species to restock its own colony. This temporary association challenges the conventional definition of an interspecific aggregation and highlights the unstable balance between different species that share the same ecological niche. Other examples of social parasitism in ants can be found in Huang and Dornhaus (2008). Nevertheless, true interspecific aggregations and cooperation are more often found in species with low levels of sociality (e.g., gregarious or communal; see the classification of sociality in Wilson [1971]), and these mixed groups can result from different behaviours and more-or-less complex interactions between species. This review attempts to assemble a comprehensive inventory of mixed-species arthropod groups through the perspective of collective behaviour.

\section{Definitions}

First, it is important to draw a distinction between temporary groupings of individuals (groups that only form for mating or feeding) from gregariousness. This review focuses on mixed-species aggregations, i.e., groups in which members of different species actively aggregate and remain together regardless of environmental heterogeneity or reproductive attraction (Fig. 1). Several other terms are used in the literature for groups composed of individuals of different species including heterospecific, interspecific, mixed-species, multispecies or polyspecific, so for the sake of clarity, the term mixed-species will be used 
throughout this review and can refer to closely related species, species from different taxa or species from different orders (Stensland et al., 2003). Furthermore, two distinct notions can be used to characterize animal species that form groups (monospecific or mixed): socialtolerance and gregariousness. Tolerance is passive, and the underlying hypothesis is that " $a$ species' social tolerance (that) has evolved to fit its optimal population density and optimal population structure” (Barrows, 2011). This implies that individuals do not use aggregation vectors (mechanical, visual and chemical channels), thus aggregates result from the attraction of individuals to the same environmental stimulus (Hamner \& Schneider, 1986). In contrast, gregariousness is defined by Vulinec (1990) as "the tendency of an animal to aggregate with others such that the animals are in contact with one another, or are nearly so, and that the distribution of the animals in the local environment is extremely patchy”. When considering this definition, it is important to include the idea of inter-attraction, which permits animals to create and maintain groups, and such inter-attraction can be direct or indirect (stigmergy, e.g., ground marking with chemicals). An efficient way to create mixed-species groups is to communicate with similar signals or to recognize the signals of other species. We named these signals as aggregation vectors and we will use this term throughout the text. In addition, the qualitative term "extremely patchy" used by Vulinec (1990) also needs to be moderated; indeed, depending of the characteristics of the interactions, the spatial distribution of gregarious populations can, in some cases, be weakly patchy (Dambach \& Goehlen, 1999).

\section{Types of mixed-species groupings}

Mixed-species aggregations have been reported in various arthropods from aphids to butterflies and woodlice to ants (Costa, 2006) (Fig. 1), and they have been observed in terrestrial, aquatic/marine and flying arthropods (Table 1). These groups can be composed of 
juveniles, adults or, in most cases, both stages. Several kinds of mixed-species aggregations can be found: those observed in one stage (adults or juveniles), both stages, seasonally or artificially. Mixed-species groups composed of one or both stages can be frequently or occasionally observed in the wild.

A frequently reported example of larvae-only aggregation is that which occurs in necrophagous Diptera larvae (maggots; Fig. 1A). These species are very often found in mixed-species groupings on carrion. Adult females do not exhibit intra- or inter-specific social behaviour but lay their egg-batches in the same area on decaying tissue. This gathering may be due to the deposition of an aggregation pheromone during oviposition, as suggested in Rivers et al. (2011). However, Brodie et al. (2014) recently observed that eggs clustering is promoted by attractive semiochemicals produced by carrion flies while regurgitating and feeding on carrion. Gravid and nongravid individuals can detect such attractants, which rejects the idea of aggregations being mediated by oviposition pheromones. Whatever its form (tactile, chemical or visual), the eggs aggregation promotes the initial grouping of several species at the same place. This gathering is later reinforced and maintained by the active aggregation behaviour of the larvae (Boulay et al., 2013, 2016). However, as soon as larvae reach the pre-pupal stage, they leave the corpse and become strongly selfish for the rest of their lives.

Gatherings can also occur due to stochastic phenomena (i.e. by chance) (BrionesFourzán et al., 2008) or because one species is exceptionally present (Ayres et al., 2001). A different degree of territoriality can also promote mixed-species groups (Grinsted et al., 2012). Such a case have been reported for two lobster species, Panulirus guttatus and $P$. argus, (Table 1). These two species occasionally share the same shelters without competition (Lozano-Álvarez et al., 2007); P. guttatus tends to climb along the walls while P. argus 
occupies the floor. Each species uses the shelter space differently, which promotes coexistence, and the aggregation allows $P$. argus to share the alarm odours of $P$. guttatus, enhancing protection against predators. Briones-Fourzán et al. (2008) suggested that such rarely observed mixed-species groups could be chemically mediated, but no evidence has been found. Some mixed-species groups also appear at a specific time each year.

Ladybeetles, or ladybugs, form large, mixed-species aggregations inside buildings during winter (Simpson \& Welborn, 1975; Lee 1980), and by forming such groups, they limit heat loss and reduce their mortality (Copp, 1983).

Lastly, some artificial groups have only been observed under laboratory conditions. Some of them have been created from highly social species, such as ants or termites, while others gathered gregarious species (Table 1). Hodge and Storfer-Isser (1997) create artificial mixed-species spider clusters by provisioning the group with sufficient food until the adult instar was reached. Such an environmental condition and sericophily enabled sociality (aggregation) that does not exist in the wild, highlighting a possible effect of habituation/collective breeding. By experimentally modifying the environmental conditions, Hodge and Storfer-Isser (1997) forced a species that naturally aggregates with conspecifics to assemble with heterospecifics. Similar results were observed by Warburg (2000) in scorpions.

Such artificial groups are interesting models to explore the minimum parameters needed to form mixed-species groups. These studies also highlight the crucial role of early social experience on the ontogeny of kin and nestmate recognition, and their results support the fact that mixed-species groups are often composed of phylogenetically related species (Table 1.) Phylogenetic proximity likely facilitates cross-species recognition, which is a necessary mechanism to initiate and maintain mixed-species groups. Such proximity also 
allows the use of similar aggregation signals (visual, chemical, etc.), thus facilitating the formation of mixed-species groups.

\section{Aggregation vectors and cross-species recognition}

To aggregate, stabilize, shape, reassemble or even split a group, gregarious species need efficient aggregation vectors (Lachmann et al., 2000), which in arthropods are often based on the perception of chemical cues (e.g., cuticular hydrocarbons) as occurs in cockroaches (Amé et al., 2004) or ladybirds (Durieux et al., 2012). Despite being mostly unknown, interspecific chemical signals are also likely involved in mixed-species groups as vectors for cross-species aggregation. Wertheim (2005) highlighted three types of interspecific chemical interactions with (i) natural enemies (predator-prey relationship), (ii) microbial organisms (e.g., the relation between Drosophila antiqua aggregation pheromones and microbial or fungal growth), and (iii) the ecological community. For this last interaction, Wertheim (2005) highlights that the composition of the aggregation pheromones of some closely related species are similar, and this chemical similarity promotes mixed-species groups. A well-known example of information sharing in mixed-species groups are cockroaches. Everaerts et al. (1997) reared two species of cockroaches together, namely, Nauphoeta cinera and Leucophaea maderae, in the same environment. Under natural conditions, the chemical profiles of these two cockroach species are highly species-specific and used for intraspecific aggregations (Lihoreau \& Rivault, 2009), but when reared together, these two species established interspecific chemical communication. Far from expressing simple tolerance behaviour (Fig. 2), the individuals aggregated together, increasing the size of the group (Everaerts et al., 1997). The authors also observed a change in the chemical profile of the hydrocarbons in both species. Everaerts et al. (1997) hypothesized that this hydrocarbon transfer occurred during the frequent physical contact among group members, 
and such contact typically occurs in the early life stages of individuals and persists over time. In 1994, Errard reared Manica rubida and Formica selysi, two ant species, in a mixed-species colony for different time periods and observed a gradual increase in the tolerance behaviour of both species. Furthermore, the individual hydrocarbon profiles of both species gradually acquired the chemical profile of the mixed colony (Errard, 1994). The establishment of the social group occurred in the early adult stage and was maintained through imprinting of mixed-colony cuticular hydrocarbons. Interestingly, the individuals reared in the mixedspecies colony were not attacked by allospecific individuals reared with non-mixed nestmates, suggesting that there is a minimal quantity of allospecific hydrocarbon compounds necessary for allospecific recognition (Errard, 1994). Vienne et al. (1995) also observed a similarity between hydrocarbon profiles in two ant species. One species being more tactile (dominant species) than the other, the touching between individuals created a common cuticular hydrocarbons profile in this mixed-species. While apparently simple, this process is favoured by relative phylogenetic proximity among species and long cumulative physical contact to allow chemical transfer.

The cross-species recognition is an essential mechanism to create and maintain mixed-species aggregation. The phylogenetic proximity between species can favour such recognition and so promote the formation of mixed-species groups. Related species often share some communication abilities (chemical, tactile or visual channels) that facilitate the communication between individuals. Regarding mixed-species groups listed in the Table 1, more than a half (55\%) are composed by species of the same taxa and $10 \%$ are composed by relative related species (pairwise divergence time inferior to 100 MYA (Million Years Ago) based on timetree.org). This observation support the hypothesis that the phylogenetic proximity facilitates the formation of mixed-species. But such proximity is not a necessary 
condition for individuals to form mixed groups. Indeed, 30\% of mixed-species groups listed are composed by species with a pairwise divergence time superior to 100 MYA (for 5\% of listed examples there is no data; timetree.org). Even if the phylogenetic proximity between species favour the formation of mixed-species groups, it may also increase the competition as these species likely share close ecological niches (Kaplan \& Denno, 2007). A trade-off seems to stand out between the formation and the maintain of mixed-species groups. Such balance is between the sharing of communications ways (increased by the phylogenetic proximity) and the risk of competition (decreased by a relative divergence of the species).

Three extreme cases of interactions can maintain members in mixed-species groups (Fig. 2). First, tolerant species can create a group that is only based on having the same preferences (e.g., shaded places), which is a non-social way to aggregate; such a case has been reported in crustaceans (Lozano-Álvarez et al., 2007). Cross-species recognition can also be a one-way mechanism, meaning that one species is a tolerant leader or nuclear species that forms the mixed-species group (Srinivasan et al., 2010). Palestrini et al. (1998) observed such unbalanced interspecific attraction in dung beetles. However, in many cases, crossspecies recognition is a two-way mechanism (see examples in Table 1), which requires two species to be able to recognize each other and exchange information; such a case has been suggested by Boulay et al. (2016) to explain frequent mixed-species groups of Calliphoridae larvae. This kind of mechanism relies on equal exchange between species, meaning that both intraspecific and interspecific attraction are similar.

However, the one-way and two-way mechanisms represent two extreme situations, and various experimental results strongly suggest that two-way recognition is not always symmetrical; more often, individuals prefer conspecifics. Accordingly, Broly et al. (2016) suggested a stronger intraspecific attraction relative to interspecific attraction in woodlice groupings. In contrast, Meadows and Mitchell (1973) observed a stronger aggregation of 
Pagurus bernhardus with crabs of another species. However, although beneficial in the context of aggregation, identical aggregation vectors can also be a constraint due to overlapping signals. These signals can hamper responders from distinguishing intraspecific members, which may explain the advantage of an asymmetric mechanism.

Arthropods can also use physical communication to form mixed-species groups. Hodge and Storfer-Isser (1997) described the utilization of chemical and vibrational cues as aggregation vectors in two web-building spiders, Hypochilus thorelli and Achaearanea tepidariorum. This aggregation is supported by an interspecific attraction to silk that favours the formation and maintenance of the group in one web site. As shown by Devigne et al. (2011) and Broly et al. (2012) in woodlice, thigmotactism (i.e., the search for contact) can also be a strong aggregation vector. The use of simple visual cues can also lead to the formation of mixed-species groups. Mizell et al. (2012) described evidence of visual responses to conspecific and heterospecific congeners in two leafhopper species, Homalodisca vitripennis and Oncometopia nigricans. The authors used visual baits, such as leafhopper cadavers or coloured models, to attract individuals, and found that the presence of conspecifics or heterospecific congeners was used by the two species to estimate the quality of the host plant. The authors also observed that $H$. vitripennis responded to cadavers of the similarly sized heterospecific $O$. nigricans. Using this information, the leafhoppers chose to rejoin the heterospecific congeners on the same host plants. Similarly, Lecchini et al. (2010) showed that postlarval crustaceans preferentially used visual cues over chemical cues to detect heterospecific individuals and thus select their habitat. Indeed, individuals rely on the presence of heterospecific crustacean congeners to determine habitat quality, which could explain mixed-species aggregations.

\section{Benefits}

This article is protected by copyright. All rights reserved. 
The notion of gregariousness often implies cooperation and/or competition, and these two phenomena are the most fundamental principles that drive the evolution of social structures. In 1931, Allee was the first to observe and to experimentally test for a positive relationship between a fitness component and population size or density (Stephens \& Sutherland, 1999; Courchamp et al., 2008). Indeed, aggregation offers direct benefits for group members and gathers reproductive individuals together, thereby facilitating reproduction. Based on this pioneering study, Odum (1953) named this relationship the Allee principle, which is more widely known as the 'Allee effect'. However, there are only a few empirical and theoretical studies of the consequences of the Allee effect for mixed-species animal groups (Courchamp et al., 1999).

First, the benefits of aggregation can simply result from the number of individuals. Known examples of such benefits include protection against predators, protection against environmental constraints or foraging advantages (Parrish \& Edelstein-Keshet, 1999; Riipi et al., 2001; Weed, 2010). One of the most studied benefits of aggregation is protection against predators, which is commonly said to be one of the main advantages of aggregation (Evans \& Schmidt, 1990; Vulinec, 1990). Predation risk is reduced by the presence of many individuals whose detection abilities are specific to their species (receptors increased). Cooperative defence (i.e., an increase in the number of predator detectors), also known as the many eyes and ears theory, is one of the few benefits that has been studied in mixed-species groups. Indeed, this mechanism could be more efficient in a mixed-species group because each species contributes its specific predator detection abilities. In insects, Pasteels and Gregoire (1984) reported a defensive aggregation of two chrysomelid larvae, Phratora vitellinae and Plagiodera versicolora, on a Salix tree. These two species secrete a defensive substance against the female sawfly, Tenthredo olivacea, their common predator. According to the 
authors, the aggregation may be a social adaptation to efficiently repel enemies and increase the chance of survival. On the other side, the transmission of disease within aggregation is an important aspect that shouldn't be ignored (Wilson et al., 2003). But in the case of mixedspecies groups, such transmission could also be decreased, as has been suggested to occur in maggots (Rivers et al., 2011; Wilson et al., 2015).

The advantages of mixed-species groups can also be attributed to the direct increase in group size (just as in single-species aggregations); i.e., individuals cooperate to reach an optimal group size so that each individual will gain direct benefits. When different species gather, even more individuals can be aggregated and more benefits can be gained. A striking example is provided by terrestrial crustaceous woodlice, for which desiccation is a major concern as they are very sensitive to water loss. In response to this environmental stress, aggregation has been shown to offer protection against drying (Broly et al., 2014) (Fig. 1D). In this context, Hassall et al. (2005) also demonstrated that two species of woodlice, Porcellio scaber and Armadillidium vulgare, can clump together (see also Caubet \& Richard [2015]). Consistent with the Allee effect, these authors found that at low densities, mixedspecies groups promote population growth that results in positive fitness consequences (higher growth rates and survivorship of group members) (Hassall et al., 2005). Furthermore, A. vulgare is more resistant to desiccation than P. scaber (Hassall et al., 2010), and Broly et al. (2015) demonstrated that body shape explains the difference in the mass-specific water loss rates. As a likely consequence, $P$. scaber aggregates more than $A$. vulgare (Hassall et al., 2005), and it can be supposed that $P$. scaber joins with $A$. vulgare to form a larger group that is better able to withstand low relative humidity and/or high ambient temperatures. For monospecific groups, the selfish herd theory postulates that individuals placed at the centre of an aggregation reduce their risk of harm compared to conspecifics present at the vanguard 
(Parrish \& Edelstein-Keshet, 1999). Such a mechanism holds for mixed-species groups, and may evenly be amplified by the different characteristics of the species.

Living together may also improve access to food. Hassall et al. (2005) hypothesized that mixed-species woodlice aggregations provide individuals with an additional food resource because these species are detritivorous and feed on each other's faeces. Another interesting example is provided by the larvae of carrion flies (Diptera: Calliphoridae) (Rivers et al., 2011) (Fig. 1A), whose maggot masses can gather hundreds to thousands of individuals of several species and instars. These larvae secrete digestive enzymes and antibiotics, and their movements mechanically liquefy muscles to facilitate the assimilation of food (exodigestion). This benefit is likely a consequence of a simple numerical effect; if more individuals are present in a group (regardless of the species), more salivary enzymes are produced (Wilson et al., 2015). Moreover, larvae secrete species-specific antibiotics (Rivers et al., 2011) that decrease the number of pathogens on the carrion and thus increase larval survival. In this context, Ives (1991) quantified the strength of larval competition in carrion flies and demonstrated a reduction in interspecific competition relative to intraspecific competition through resource partitioning.

Thus, mixed-species can offer advantages that are not available to small monospecific groups. Furthermore, the addition of two or more species can yield different benefits than those observed in monospecific groups (e.g., different sensory abilities). However, while it may seem that the benefits of grouping are more or less equally shared when individuals belong to the same species, this assumption becomes questionable for groups composed of different species. In other words, one may ask if for the same group size, a monospecific group can be more effective than a mixed one. An initial response to this question is that the accumulation of the different abilities of the species in a mixed group can generate benefits that cannot be matched in the monospecific group. Such a phenomenon has been previously 
reported in mammals (Stensland et al., 2003), and Roth and Willis (1960) suggest that it can also be true in arthropods. Through the association of the abilities of different species (cooperation), the benefits/deleterious effects ratio can be better compared to that observed in a monospecific group. Furthermore, species that form mixed societies mostly do not have the exact same ecological niche, which decreases the competition for food. All of this raises the question of benefit symmetry among group members. In social foraging groups, the producer-scrounger game is one of mathematical models used to describe the individual foraging strategies of group members (Giraldeau \& Caraco, 2000). This model highlights the exploitation of a producer's findings (e.g., resource sites) by scroungers and predicts how foraging strategies change with food patch size. It also predicts how individuals can switch between the two strategies, scrounging or producing, until they reach an evolutionarily stable strategy (Giraldeau \& Beauchamp, 1999). Such models have been used for many bird species (Giraldeau \& Caraco, 2000; Sumpter, 2010) but, to our knowledge, only in non-mixed species groups. However, this model could be modified to describe the foraging strategies of mixed-species groups by adding parameters to quantify the different foraging abilities of each species. Such an upgraded model would be useful for predicting the ways in which species search and compete for resources in mixed groups.

\section{Species competition}

The question of competition is a key point in understanding mixed-species groupings. Surprisingly, even though mixed-species groups are interesting models for exploring the balance between collective benefits, species-specific benefits and competition within species and individuals, almost no experimental data can be found in the literature (Fig. 3).

The close proximity of competitors that occupy the same ecological niche decreases food availability or the accessibility of reproductive partners, so competition can emerge 
between members of mixed-species groups in habitats with insufficient food resources. However, Anne and Rasa (1989) suggest that competition decreases in mixed-species rather than single-species groups; individuals must compete for all of their resources in monospecific groups, while competition may be for only a single resource (food) in mixedspecies groups (Anne \& Rasa, 1989). Consistent with this idea, Reis et al. (1999) observed a higher survival rate in double-species groups composed of Chrysomya putoria and Cochliomyia macellaria when they increased the larval density of both species. However, they also showed that C. macellaria is an inferior competitor in the presence of Ch. putoria, as before coexistence depends on the condition that the cadaver size is not limiting. Thus, even if aggregation offers advantages, there may also be unbalanced relationships in mixedspecies groups or even social parasitism, in which some species disproportionately benefit from the competitive abilities of another species. Moreover, the mechanical exclusion of one species by another may also occur, or the trade-offs between the species may change over time. At first, individuals of one species may gain from cooperating with those of another species to form a group, but once the group is formed and stable, species can mutually separate once their optimal group size is reached. If the two species have sufficiently different ecological niches, they can segregate but remain in contact (Figs. 1A \& 3). This mechanism has been observed in two larval Diptera species, Chrysomya albiceps and $C$. marginalis (Villet et al., 2010). These species grow faster at high temperatures, but each one has its own thermic preferendum. Due to their abilities to produce heat (larval-mass effect), they can aggregate together and increase local temperature. However, such aggregates split when mass-temperature start to exceed the tolerance of one species (Rivers et al., 2011). Competition for access to food was observed in necrophagous larvae, which densely aggregate on carrion. Inside these larval masses, individuals try to reach the food located under the mass and thus crawl over each other in a movement described as "scramble 
competition" (Rivers et al., 2011). However, Charabidze et al. $(2011,2013)$ highlighted that these masses are more structured than typically thought; according to the self-organization theory, a complex structure can emerge from larval foraging behaviour, allowing them to feed more efficiently. More generally speaking, while the resource is not limiting, species can occupy a similar/identical ecological niche without experiencing the effects of competition, as in leaf-feeding aphids (Hajek \& Dahlsten, 1986). However, many resources are restricted in quantity, time or space, which may contribute to restricting the ecological niches that are suitable for mixed-species groups.

\section{Conclusion}

Based on this review of the literature, mixed-species aggregations appear to be found in a wide range of arthropod taxa (Table 1). The phylogenetic proximity tends to favour the formation and the maintaining of such groups, likely due to similar scales (size, lifespan, displacement, etc.) and an easier communication between members. However, the degree to which the speciation process may be linked to the existence of stable mixed-species groups remains to be answered. Mixed-species groups do not seem to be restricted by the degree of sociality of the species; they have been observed in species ranging from gregarious to eusocial. Drawing on this, this review raises the question of the proximate and ultimate causes favouring such mixed-species groups, and one conclusion is the importance of the spatial distribution/specialization of the species. Obviously, natural mixed-species grouping is restricted to species of approximately the same size that at least partly share the same area during the same period of time. Species that form stable social groups are also more likely to accept individuals from another species. Furthermore, closely related species are likely to share similar aggregation cues (e.g., related chemical compounds) and detection abilities, which facilitates cross-species recognition and, probably, the formation of mixed-species 
groups. But theoretical models also show that the cues of both species do not need to perfectly overlap to produce mixed-species groups (Nicolis et al., 2016). Furthermore, mixed-species groups can also be observed if the inter-attraction between species is less than the intraspecific attraction but greater than a critical value. The similarity of the cues of the two species modulates the inter-attraction between them (Nicolis et al., 2016).

Blends of chemical compounds (e.g., hydrocarbons) are the most common aggregation cues used by arthropods. Experiments on cross-species chemical recognition have been performed in only a restricted number of species, but they could provide an interesting starting point for understanding the mechanisms driving mixed-species aggregation dynamics, especially in the context of self-organization. Indeed, such aggregation dynamics result from a network of feedbacks, mainly the amplification of positive feedbacks resulting from inter-attraction, and this concept successfully explains how interactions between individuals can generate complex collective systems. Furthermore, selforganization is associated with the notion of emergence (a phenomenon is emergent when observers cannot predict its appearance based only on the knowledge of the behaviour of the components of the system). From unicellular organisms to mammals, this theory has been used to describe collective phenomena and to explain how individuals can form, amplify, regulate or divide groups; many examples of emergent phenomena are described in Camazine et al. (2001). In the case of mixed groups, self-organized models predict different collective behaviours without the need to change the behaviour of any individuals. Some generic parameters, such as resource availability (e.g., the carrying capacity) or the number of individuals involved, are the keys to shaping the aggregates. A simple but striking consequence is the possibility for species to segregate even in absence of agonistic behaviour (Nicolis et al., 2016). 
From a purposive point of view, mixed-species groups likely provide similar benefits to members as intraspecific groups, a conclusion that was also drawn from mixed-species groups of mammals (Stensland et al., 2003). These benefits essentially include enhancing protection against predators and shared foraging strategies (Table 1), and as shown by the examples in this review, mixed-species groups can be stable in time and mutually beneficial, especially if the species do not have the same ecological niche or if resources are not limiting. In such cases, the competition between species should play a secondary role, and both species can benefit from the aggregation and the resulting cooperation. However, interspecific competition can quickly direct the benefits disproportionately towards one species at the expense of the other. Experimental and theoretical results show that an increase in competition can lead to new patterns and a shift towards segregation (Leoncini \& Rivault, 2005; Nicolis et al., 2016). Accordingly, the study of mixed-species groups offers an interesting way to investigate the frontiers between cooperation and competition.

Compared to intraspecific groups, and especially eusocial species, our understanding of mixed-species groups of arthropods is at an early stage (see the review by Jeanson et al. [2012]), but most of the experimental designs used to study monospecific groups, such as the binary choice test, can be applying to the study of mixed-species groups (Boulay et al., 2016; Leoncini \& Rivault, 2005). Several marking techniques also exist to follow individuals, which can facilitate the monitoring of species during experiments (Hagler \& Jackson, 2001), and such technical approaches provide a good working basis for further experimentation on mixed-species groups. Moreover, various theories, mathematical models and metrics have been developed in the context of aggregation and could be applied or adapted to mixedspecies groups (for metrics, see Everaerts et al. [1997], Ives [1991], Sauphanor and Sureau [1993]or Caubet and Richard [2015]; for models, see Deneubourg et al. [1991) or Nicolis et al. [2016]). However, models of the cooperation-competition phenomenon still need to be 
established for mixed-species groups, but the required experimental data are currently lacking.

\section{Acknowledgments}

The authors would like to thank Robert Oelman (photographer), Cameron Richards (PhD) and Nash Turley (postdoctoral researcher) for permitting us to reuse their photos. Jean-Louis Deneubourg is a Senior Research Associate from the F.R.S.-FNRS.

\section{Disclosure}

The authors declare no competing interests.

\section{References}

Allee, W.C. (1931) Animal Aggregations: A Study in General Sociology. Chicago: The University of Chicago Press.

Ame, J.M., Rivault, C. and Deneubourg, J.L. (2004) Cockroach aggregation based on strain odour recognition. Animal Behaviour, 68, 793-801.

Anne, O. and Rasa, E. (1989) Interspecific defence aggregations: a model for the evolution of sociality and kin selection. Netherlands Journal of Zoology, 40, 711-728.

Arnaud, L., Lognay, G., Verscheure, M., Leenaers, L., Gaspar, C. and Haubruge, E. (2002) Is dimethyldecanal a common aggregation pheromone of Tribolium flour beetles? Journal of Chemical Ecology, 28, 523-532.

Ayres, B.D., Ayres, M.P., Abrahamson, M.D. and Teale, S.A. (2001) Resource partitioning and overlap in three sympatric species of Ips bark beetles (Coleoptera: Scolytidae). Oecologia, 128, 443-453.

This article is protected by copyright. All rights reserved. 
Barrows, E.M. (2011) Animal Behavior Desk Reference: A Dictionary of Animal Behavior, Ecology, and Evolution. Third Edition. New York: CRC Press.

Bartelt, R.J., Seaton, K.L. and Dowd, P.F. (1993) Aggregation pheromone of Carpophilus antiquus (Coleoptera: Nitidulidae) and kairomonal use of C. lugubris pheromone by C. antiquus. Journal of Chemical Ecology, 19, 2203-2216.

Bartelt, R.J., Weaver, D.K. and Arbogast, R.T. (1995) Aggregation pheromone of Carpophilus dimidiatus (F.) (Coleoptera: Nitidulidae) and responses to Carpophilus pheromones in South Carolina. Journal of Chemical Ecology, 21, 1763-1779.

Bogner, F.X. (1996) Interspecific advantage results in intraspecific disadvantage: chemical protection versus cannibalism in Utetheisa ornatrix (Lepidoptera: Arctiidae). Journal of Chemical Ecology, 22, 1439-1451.

Boulay, J., Deneubourg, J.L., Hedouin, V. and Charabidze D. (2016) Interspecific shared collective decision-making in two forensically important species. Proceedings of the Royal Society B, 283, 20152676.

Boulay, J., Devigne, C., Gosset, D. and Charabidze, D. (2013) Evidence of active aggregation behaviour in Lucilia sericata larvae and possible implication of a conspecific mark. Animal Behaviour, 85, 1191-1197.

Briones-Fourzan, P., Ramirez-Zaldivar, E. and Lozano-Alvarez, E. (2008) Influence of conspecific and heterospecific aggregation cues and alarm odors on shelter choice by syntopic spiny lobsters. The Biological Bulletin, 215, 182-190.

Brodie, B.S., Wong, W.H.L., VanLaerhoven, S. and Gries, G. (2014) Is aggregated oviposition by the blow flies Lucilia sericata and Phormia regina (Diptera: Calliphoridae) really pheromone-mediated? Insect Science, 22, 651-660.

This article is protected by copyright. All rights reserved. 
Broly, P., Devigne, L., Deneubourg, J.L. and Devigne, C. (2014) Effects of group size on aggregation against desiccation in woodlice (Isopoda: Oniscidea). Physiological Entomology, 39, 165-171.

Broly, P., Devigne, C. and Deneubourg, J.-L. (2015) Body shape in terrestrial isopods: a morphological mechanism to resist desiccation? Journal of Morphology, 276, 1283 9.

Broly, P., Ectors, Q., Decuyper, G., Nicolis, S.C. and Deneubourg, J.-L. (2016) Sensitivity of density-dependent threshold to species composition in arthropod aggregates. Scientific Reports, 6, 32576.

Camazine, S., Deneubourg, J.-L., Franks, N.R., Sneyd, J., Theraulaz, G. and Bonabeau, E. (2001) Self-Organization in Biological Systems. Princeton: Princeton University Press.

Caubet, Y. and Richard, F.J. (2015) NEIGHBOUR-IN: image processing software for spatial analysis of animal grouping. ZooKeys, 515, 173-189.

Charabidze, D., Bourel, B. and Gosset, D. (2011) Larval-mass effect: characterisation of heat emission by necrophageous blowflies (Diptera: Calliphoridae) larval aggregates. Forensic Science International, 211, 61-66.

Charabidze, D., Hedouin, V. and Gosset, D. (2013) Discontinuous foraging behavior of necrophagous Lucilia sericata (Meigen 1826) (Diptera Calliphoridae) larvae. Journal of Insect Physiology, 59, 325-331.

Chatterton, B.D.E. and Fortey, R.A. (2008) Linear clusters of articulated trilobites from the lower ordovician (Arenig) strata at Bini Tinzoulin, North of Zagora, Southern Morocco. Advances in Trilobite Research (eds. I. Rábano, R. Gozalo \& D. GarcíaBellido), pp 73-78. Mandrid: Instituto Geológico y Minero de España. 
Chelini, M.C., Willemart, R.H. and Gnaspini, P. (2012) Gregarious behavior of two species of Neotropical harvestmen (Arachnida: Opiliones: Gonyleptidae). The Journal of Arachnology, 40, 256-258.

Choe, J.C. and Crespi, B.J. (1997) The Evolution of Social Behaviour in Insects and Arachnids. Cambridge: Cambridge University Press.

Copp, N.H. (1983) Temperature-dependent behaviours and cluster formation by aggregating ladybird beetles. Animal Behaviour, 31, 424-430.

Costa, J.T. (2006) The Other Insect Societies. England: Belknap Press of Harvard University Press.

Costa, J.T. and Fitzgerald, T.D. (2005) Social terminology revisited: where are we ten years later? Annales Zoologici Fennici, 42, 559-564.

Courchamp, F., Berec, L. and Gascoigne, J. (2008) Allee Effects in Ecology and Conservation. New York: Oxford University Press.

Courchamp, F., Clutton-Brock, T. and Grenfell, B. (1999) Inverse density dependence and the Allee effect. Trends in Ecology \& Evolution, 14, 405-410.

Dambach, M. and Goehlen, B. (1999) Aggregation density and longevity correlate with humidity in first-instar nymphs of the cockroach (Blattella germanica L., Dictyoptera). Journal of Insect Physiology, 45, 423-429.

Deneubourg, J.L., Goss, S., Franks, N., Sendova-Franks, A., Detrain, C. and Chrétien, L. (1991) The dynamics of collective sorting robot-like ants and ant-like robots. From Animals to Animats: Simulation of Adaptive Behavior (eds. J.A. Meyer and S.W. Wilson, pp 356-365. Cambridge, MA: MIT Press.

Devigne, C., Broly, P. and Deneubourg, J.-L. (2011) Individual preferences and social interactions determine the aggregation of woodlice. PLoS ONE, 6, e17389.

This article is protected by copyright. All rights reserved. 
Durieux, D., Fisher, C, Brostaux, Y., Sloggett, J.J., Deneubourg, J.L., Vandereycken, A. et al. (2012) Role of long-chain hydrocarbons in the aggregation behaviour of Harmonia axyridis (Pallas) (Coleoptera: Coccinellidae). Journal of Insect Physiology, 58, 801807.

Errard, C. (1994) Development of interspecific recognition behavior in the ants Manica rubida and Formica selysi (Hymenoptera: Formicidae) reared in mixed-species groups. Journal of Insect Behavior, 7, 83-99.

Evans, D.L. and Schmidt, J.O. (1990) Insect Defenses: Adaptive Mechanisms and Strategies of Prey and Predators. Albany: Sate University of New-York Press.

Everaerts, C., Farine, J.P. and Brossut, R. (1997) Changes of species specific cuticular hydrocarbon profiles in the cockroaches Nauphoeta cinerea and Leucophaea maderae reared in heterospecific groups. Entomologia Experimentalis et Applicata, $85,145-150$.

Farine, D.R., Aplin, L.M., Garroway, C.J., Mann, R.P. and Sheldon, B.C. (2014a) Collective decision making and social interaction rules in mixed-species flocks of songbirds. Animal Behaviour, 95, 173 - 182.

Farine, D.R., Downing, C.P. and Downing, P.A. (2014b) Mixed-species associations can arise without heterospecific attraction. Behavioral Ecology, 25, 574- 581.

Fielde, A.M. (1903) Artificial mixed nests of ants. Biological Bulletin, 5, 320-325.

Fitzgerald, T.D. and Edgerly, J.S. (1979) Specificity of trail markers of forest and eastern tent caterpillars. Journal of Chemical Ecology, 5, 565-574.

Fucarino, A., Millar, J.G., McElfresh, J.S. and Colazza, S. (2004) Chemical and physical signals mediating conspecific and heterospecific aggregation behavior of first instar stink bugs. Journal of Chemical Ecology, 30, 1257-1269.

This article is protected by copyright. All rights reserved. 
Giraldeau, L.A. and Caraco, T. (2000) Social Foraging Theory. Princeton, NJ: Princeton University Press.

Giraldeau, L.A. and Beauchamp, G. (1999) Food exploitation: searching for the optimal joining policy. Trends in Ecology \& Evolution, 14, 102-106.

Grinsted, L., Agnarsson, I. and Bilde, T. (2012) Subsocial behaviour and brood adoption in mixed-species colonies of two theridiid spiders. Naturwissenschaften, 99, 10211030.

Gunn, A. and Bird, J. (2011) The ability of the blowflies Calliphora vomitoria (Linnaeus), Calliphora vicina (Rob-Desvoidy) and Lucilia sericata (Meigen) (Diptera:

Calliphoridae) and the muscid flies Muscina stabulans (Fallen) and Muscina prolapsa (Harris) (Diptera: Muscidae) to colonise buried remains. Forensic Science International, 207, 198-204.

Hagler, J.R. and Jackson, C.G. (2001) Methods for marking insects: current techniques and future prospects. Annual Review of Entomology, 46, 511-543.

Hajek, A.E. and Dahlsten, D.L. (1986) Coexistence of three species of leaf-feeding aphids (Homoptera) on Betula pendula. Oecologia, 68, 380-386.

Hamner, W.M. and Schneider, D. (1986) Regularly spaced rows of medusae in the Bering Sea: role of Langmuir circulation. Limnology and Oceanography, 31, 171-176.

Hassall, M., Tuck, J.M. and James, R. (2005) Effects of density and spatial heterogeneity on foraging behaviour and fitness correlates of Armadillidium vulgare (Isopoda Oniscidea). Ethology Ecology \& Evolution, 17, 233-247.

Hassall, M., Edwards, D.P., Carmenta, R., Derhé, M.A. and Moss, A. (2010) Predicting the effect of climate change on aggregation behaviour in four species of terrestrial isopods. Behaviour, 147, 151-164.

This article is protected by copyright. All rights reserved. 
Heinrich, B. and Vogt, F.D. (1980) Aggregation and foraging behavior of whirligig beetles (Gyrinidae). Behavioral Ecology and Sociobiology, 7, 179-186.

Hodge, M.A. and Storfer-Isser, A. (1997) Conspecific and heterospecific attraction: a mechanism of web-site selection leading to aggregation formation by web-building spiders. Ethology, 103, 815-826.

Honek, A., Martinkova, Z. and Pekar, S. (2007) Aggregation characteristics of three species of Coccinellidae (Coleoptera) at hibernation sites. European Journal of Entomology, $104,51-56$.

Huang, M.H. and Dornhaus, A. (2008) A meta-analysis of ant social parasitism: host characteristics of different parasitism types and a test of Emery's rule. Ecological Entomology, 33, 589-596.

Ishiwatari, T. (1976) Studies on the scent of stink bugs (Hemiptera: Pentatomidae): II. aggregation pheromone activity. Applied Entomology and Zoology, 11, 38-44.

Ives, A.R. (1991) Aggregation and coexistence in a carrion fly community. Ecological Monographs, 61, 75-94.

Jaenike, J. and James, A.C. (1991) Aggregation and the coexistence of mycophagous Drosophila. Journal of Animal Ecology, 60, 913-928.

Jeanson, R., Dussutour, A. and Fourcassié, V. (2012) Key factors for the emergence of collective decision in invertebrates. Frontiers in Neuroscience, 6, 121.

Kivelä, S.M., Seppänen, J.-T., Ovaskainen, O., Doligez, B., Gustafsson, L., Mönkkönen, M. et al. (2014) The past and the present in decision-making: the use of conspecific and heterospecific cues in nest site selection. Ecology, 95, 3428-3439.

Kaplan, I. and Denno, R.F. (2007) Interspecific interactions in phytophagous insects revisited: a quantitative assessment of competition theory. Ecology Letters, 10, $977-$ 994.

This article is protected by copyright. All rights reserved. 
Kotov, A.A. (2000) Mixed multispecific schools of littoral Anomopoda (Crustacea:

'Cladocera'). Hydrobiologia, 434, 211-212.

Krasnov, B.R., Burdelova, N.V., Khokhlova, I.S., Shenbrot, G.I. and Degen, A. (2005)

Larval interspecific competition in two flea species parasitic on the same rodent host. Ecological Entomology, 30, 146-155.

Krasnov, B.R., Stanko, M., Khokhlova, I.S., Mošanský, L., Shenbrot, G.I., Hawlena, H. et al. (2006) Aggregation and species coexistence in fleas parasitic on small mammals. Ecography, 29, 159-168.

Krause, J. and Ruxton, G.D. (2002) Living in Groups. New York: Oxford University Press.

Lachmann, M., Sella, G. and Jablonka, E. (2000) On the advantages of information sharing. Proceedings of the Royal Society of London B, 267, 1287-1293.

Le Goff, G. (2011) Benefits of aggregation in Tetranychus urticae, Université Catholique de Louvain.

Lecchini, D., Mills, S.C., Brié, C., Maurin, R. and Banaigs, B. (2010) Ecological determinants and sensory mechanisms in habitat selection of crustacean postlarvae. Behavioral Ecology, 21, 599-607.

Lee, R.E. (1980) Aggregation of lady beetles on the shores of lakes (Coleoptera: Coccinellidae). The American Midland Naturalist, 104, 295-304.

Leoncini, I. and Rivault, C. (2005) Could species segregation be a consequence of aggregation processes? Example of Periplaneta americana (L.) and P. fuliginosa (Serville). Ethology, 111, 527-540.

Lihoreau, M. and Rivault, C. (2009) Kin recognition via cuticular hydrocarbons shapes cockroach social life. Behavioral Ecology, 20, 46-53.

This article is protected by copyright. All rights reserved. 
Lorenzo Figueiras, A.N. and Lazzari, C.R. (1998) Aggregation behaviour and interspecific responses in three species of Triatominae. Memórias do Instituto Oswaldo Cruz, 93, $133-137$.

Lozano-Álvarez, E. and Briones-Fourzán, P. (2001) Den choice and occupation patterns of shelters by two sympatric lobster species, Panulirus argus and Panulirus guttatus, under experimental conditions. Marine and Freshwater Research, 52, 1145-1155.

Lozano-Álvarez, E., Briones-Fourzán, P., Osorio-Arciniegas, A., Negrete-Soto, F. and Barradas-Ortiz, C. (2007) Coexistence of congeneric spiny lobsters on coral reefs: differential use of shelter resources and vulnerability to predators. Coral Reefs, 26, $361-373$.

Meadows, P.S. and Mitchell, K.A. (1973) An analysis of inter- and intraspecific aggregations in two sympatric species of hermit crab (Decapoda, Anomura, Paguridae). Marine Behaviour and Physiology, 2, 187-196.

Mizell, R.F., Andersen, P.C., Brodbeck, B.V. and Hunter, W.B. (2012) Congener response reduces risks from bottom-up and top-down forces: behavioral parsimony by a xylophage. American Entomologist, 58, 106.

Moreno-Ripoll, R., Agustí, N., Berruezo, R. and Gabarra, R. (2012) Conspecific and heterospecific interactions between two omnivorous predators on tomato. Biological Control, 62, 189-196.

Mota, T. and Lorenzo, M.G. (2012) Lack of segregation between two species of Chagas disease vectors. The American Journal of Tropical Medicine and Hygiene, 87, 109116.

Niassy, A., Torto, B., Njagi, P.G.N., Hassanali, A., Obeng-Ofori, D. and Ayertey, J.N. (1999) Intra- and interspecific aggregation responses of Locusta migratoria migratorioides 
and Schistocerca gregaria and a comparison of their pheromone emissions. Journal of Chemical Ecology, 25, 1029-1042.

Nicolis, S.C., Halloy, J. and Deneubourg, J.-L. (2016) Transition between segregation and aggregation: the role of environmental constraints. Scientific Reports, 6, 32703.

Odum, E.P. (1953) Fundamentals of Ecology. Philadelphia: Saunders.

Olmstead, K.L. and Wood, T.K. (1990) The effect of clutch size and ant attendance on egg guarding by Entylia bactriana (Homoptera: Membracidae). Psyche, 97, 111-120.

Palestrini, C., Barbero, E. and Ronaldo, A. (1998) Intra- and interspecific aggregation among dung beetles (Coleoptera: Scarabaeoidea) in an Alpine pasture. Journal of Zoology, 245, 101-109.

Parrish, J.K. and Edelstein-Keshet, L. (1999) Complexity, pattern, and evolutionary tradeoffs in animal aggregation. Science, 284, 99.

Passera, L. and Aron, S. (2005) Les Fourmis : Comportement, Organisation Sociale et Évolution. Ottawa: CNRC-NRC, Les Presses scientifiques du CNRC.

Pasteels, J.M. and Gregoire, J.C. (1984) Selective predation on chemically defended chrysomelid larvae. Journal of Chemical Ecology, 10, 1693-1700.

Reis, S.F.D., Von Zuben, C.J. and Godoy, W.A.C. (1999) Larval aggregation and competition for food in experimental populations of Chrysomya putoria (Wied.) and Cochliomyia macellaria (F.) (Dipt., Calliphoridae). Journal of Applied Entomology, $123,485-489$

Riipi, M., Alatalo, R.V., Lindstrom, L. and Mappes, J. (2001) Multiple benefits of gregariousness cover detectability costs in aposematic aggregations. Nature, 413, $512-514$.

This article is protected by copyright. All rights reserved. 
Rivers, D.B., Thompson, C. and Brogan, R. (2011) Physiological trade-offs of forming maggot masses by necrophagous flies on vertebrate carrion. Bulletin of Entomological Research, 101, 599-611.

Roth, L.M. and Willis, E.B. (1960) The Biotic Associations of Cockroaches. Charlottesville: Smithsonian Institution Press.

Ryan, M.F. and O'Ceallachain, D.P. (1976) Aggregation and sex pheromones in the beetle Tribolium confusum. Journal of Insect Physiology, 22, 1501-1503.

Sauphanor, B. and Sureau, F. (1993) Aggregation behaviour and interspecific relationships in Dermaptera. Oecologia, 96, 360-364.

Simpson, R.G. and Welborn, C.E. (1975) Aggregations of alfafa weevils, Hypera postica, convergent lady beetles, Hippodamia convergens, and other insects. Environmental Entomology, 4, 193.

Slone, D.H. (1999) Spatial patterns of predaceous and phytophagous apple mites (Acari: Eriophyidae, Phytoseiidae, Stigmaeidae, Tetranychidae): intra- and interspecific relationships. http://ir.library.oregonstate.edu/xmlui/handle/1957/33866 (Accessed 28 november 2016)

Sonenshine, D.E. (1985) Pheromones and other semiochemicals of the acari. Annual Review of Entomology, 30, 1-28.

Srinivasan, U., Raza, R.H. and Quader, S. (2010) The nuclear question: rethinking species importance in multi-species animal groups. Journal of Animal Ecology, 79, 948-954.

Stamps, J.A. (1988) Conspecific attraction and aggregation in territorial species. The American Naturalist, 131, 329-347.

Stanko, M., Miklisová, D., De Bellocq, J. and Morand, S. (2002) Mammal density and patterns of ectoparasite species richness and abundance. Oecologia, 131, 289-295.

This article is protected by copyright. All rights reserved. 
Stensland, E.V.A., Angerbjörn, A. and Berggren, P.E.R. (2003) Mixed species groups in mammals. Mammal Review, 33, 205-223.

Stephens, P.A. and Sutherland, W.J. (1999) Consequences of the Allee effect for behaviour, ecology and conservation. Trends in Ecology \& Evolution, 14, 401-405.

Stuart, R.J. and Alloway, T.M. (1983) The slave-making ant, Harpagoxenus canadensis M. R. Smith, and its host-species, Leptothorax muscorum (Nylander): slave raiding and territoriality. Behaviour, 85, 58-89.

Sumpter, D.J.T. (2010) Collective Behavior. Princeton: Princeton University Press.

Terborgh, J. (1990) Mixed flocks and polyspecific associations: costs and benefits of mixed groups to birds and monkeys. American Journal of Primatology, 21, 87-100.

Tsunoda, T. (2007) Interspecific and intraspecific associations of two species of hard ticks, Haemaphysalis longicornis and Haemaphysalis megaspinosa, in relation to questing site. Journal of Parasitology, 93, 531-541.

Uvarov, B.P. (1977) Grasshoppers and Locusts: A Handbook of General Acridology. Behaviour, Ecology, Biogeography, Population Dynamics. London, UK: Centre for Overseas Pest Research.

Vauchot, B., Provost, E., Bagneres, A.G. and Clement, J.L. (1996) Regulation of the chemical signatures of two termite species, Reticulitermes santonensis and Reticulitermes lucifugus grassei, living in mixed experimental colonies. Journal of Insect Physiology, 42, 309-321.

Verhoef, H., Nagelkerke, C. and Joosse, E. (1977) Aggregation pheromones in Collembola. Journal of Insect Physiology, 23, 1009-1013.

Vienne, C., Soroker, V. and Hefetz, A. (1995) Congruency of hydrocarbon patterns in heterospecific groups of ants: transfer and/or biosynthesis? Insectes Sociaux, 42, $267-277$.

This article is protected by copyright. All rights reserved. 
Villet, M.H., Richards, C.S. and Midgley, J.M. (2010) Contemporary precision, bias and accuracy of minimum post-mortem intervals estimated using development of carrionfeeding insects. Current Concepts in Forensic Entomology (eds. J. Amendt, M.L. Goff, C.P. Campobasso \& M. Grassberger), pp 109-137. Dordrecht: Springer Netherlands.

Vulinec, K. (1990) Collective security: aggregation by insects as a defense. Insect Defenses: Adaptative Mechanisms and Strategies of Prey and Predators (eds. D. L. Evans and J. O. Schmidt), pp 251-288. Albany: State University of New York Press.

Vulinec, K. and Miller, M.C. (1989) Aggregation and predator avoidance in whirligig beetles (Coleoptera: Gyrinidae). Journal of the New York Entomological Society, 97, 438447.

Warburg, M.R. (2000) Intra- and interspecific cohabitation of scorpions in the field and the effect of density, food, and shelter on their interactions. Journal of Ethology, 18, 5963.

Weed, A.S. (2010) Benefits of larval group feeding by Chrysolina aurichalcea asclepiadis on Vincetoxicum: improved host location or feeding facilitation? Entomologia Experimentalis et Applicata, 137, 220-228.

Wertheim, B. (2005) Evolutionary ecology of communication signals that induce aggregative behaviour. Oïkos, 109, 117-124.

Wertheim, B., Allemand, R., Vet, L.E.M. and Dicke, M. (2006) Effects of aggregation pheromone on individual behaviour and food web interactions: a field study on Drosophila. Ecological Entomology, 31, 216-226.

Wilson, E.O. (1971) The Insects Societies. Cambridge, MA: Belknap Press of Harvard University Press.

This article is protected by copyright. All rights reserved. 
Wilson, E.O. and Hölldobler, B. (2005) Eusociality: origin and consequences. Proceedings of the National Academy of Sciences of the United States of America, 102, 1336713371.

Wilson, K., Knell, R., Boots, M. and Koch-Osborne, J. (2003) Group living and investment in immune defence: an interspecific analysis. Journal of Animal Ecology, 72, 133-143.

Wilson, M.R., Nigam, Y., Jung, W., Knight, J. and Pritchard, D.I. (2015) The impacts of larval density and protease inhibition on feeding in medicinal larvae of the greenbottle fly Lucilia sericata. Medical and Veterinary Entomology, 30, 1-7.

Wood, T. (1979) Sociality in the Membracidae (Homoptera). Miscellaneous Publications of the Entomological Society of America, 11, 15-22.

Woodcock, B.A., Watt, A.D. and Leather, S.R. (2002) Aggregation, habitat quality and coexistence: a case study on carrion fly communities in slug cadavers. Journal of Animal Ecology, 71, 131-140.

Yoder, J.A., Reinsel, K.A., Welch, J.M., Clifford, D.M. and Rellinger, E.J. (2005) Herding limits water loss in the sand fiddler crab. Journal of Crustacean Biology, 25, 141145.

Manuscript received January 12, 2017

Final version received May 11, 2017

Accepted June 01, 2017

\section{Figures legend}

Figure 1. Examples of mixed-species groups. (A) Large mixed-species group of necrophagous Diptera larvae (Chrysomya albiceps [dark maggots] and C. marginalis [light maggots]). Species segregation is observed due to the specific thermal preferences of the 
larvae (used with permission - (C) Cameron Richards). (B) A mixed-species group of treehoppers composed of adults and nymphs (white) of Membracis elevata (black adults with a white spot on their back) and M. dorsata (adults without a white spot) found in Ecuador (used with permission - (C) Robert Oelman). (C) Lady beetles (Harmonia axyridis) and the spotted cucumber beetle (Diabrotica undecimpunctata) on grass (used with permission - (C) Nash Turley). (D) A large mixed-species group of woodlice composed of three species (Armadillidium vulgare (grey circle), Oniscus asellus (white circle) and Porcellio scaber (black circle); creative commons - Dave Ingram).

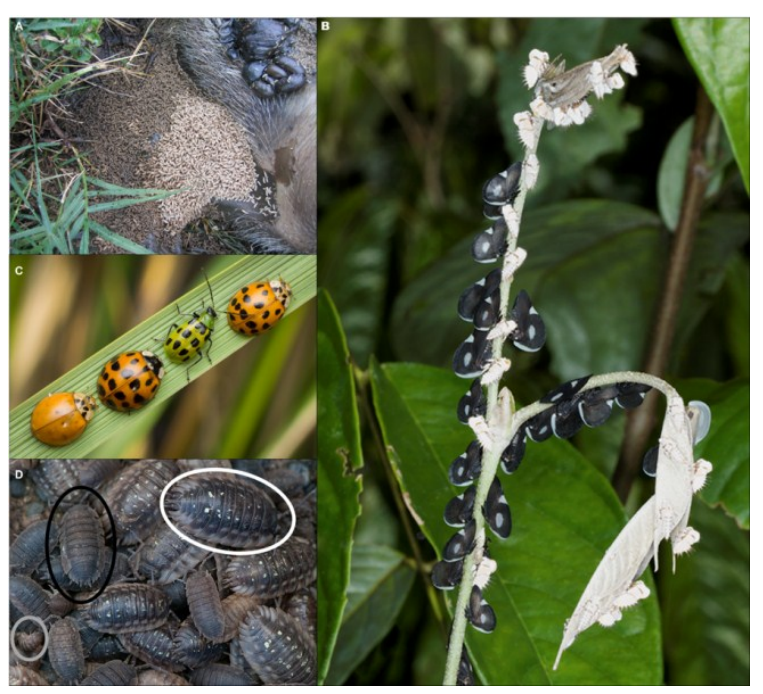

Figure 2. Three extreme cases of interactions between species conducive to the formation of mixed-species groups. The non-social way is described as a gathering of tolerant species with the same preferences for environmental heterogeneity. In the one-way mechanism, one species is a tolerant leader or nucleus that forms the mixed-species group. The two-way mechanism is a mutual attraction of both species that is conducive to the formation of the group. Sharing signals/cues conduct to the maintain of the mixed-species group in time. Arrows represent the detection of aggregation signals. 

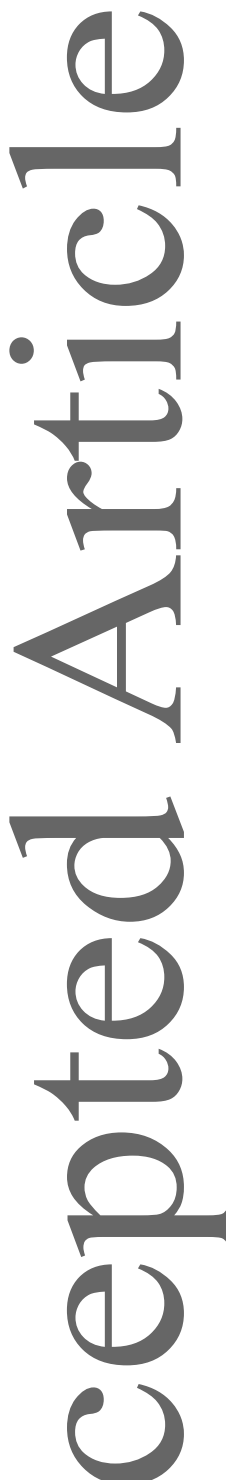
( ) neutral.

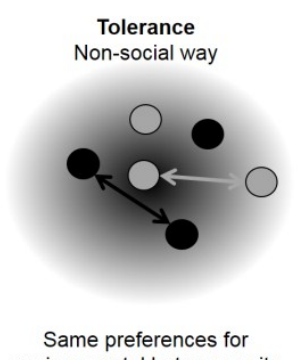

environmental heterogeneity
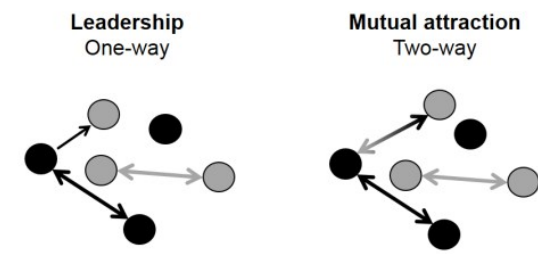

Unbalanced cross-species recognition
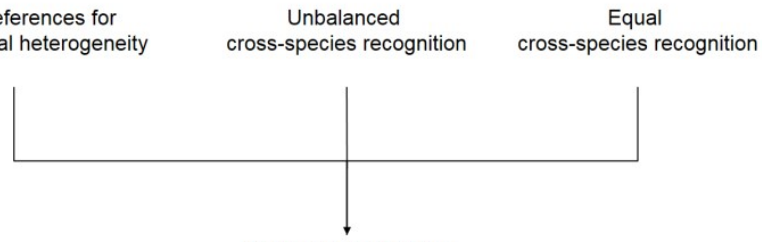

Sharing signals/cues

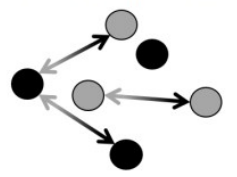

Figure 3. Schematic overview of relationship between species in mixed-species groups.

The overlap of ecological niches drives the interactions among species. Mutualism: a

relationship between two species in which both benefit from the association. Commensalism:

a relationship between two species in which one derives some benefit while the other is

unaffected. Exploitation: a relationship between two species in which one derives some

benefit while the other is negatively affected. Segregation: a competitive relationship between

two species that splits the group but the species remain in contact or close to each other.

Exclusion: a competitive relationship between two species leading to the exclusion of one species from the area. The effects on the species can be $(+)$ beneficial, (-) detrimental or $(0)$

This article is protected by copyright. All rights reserved. 


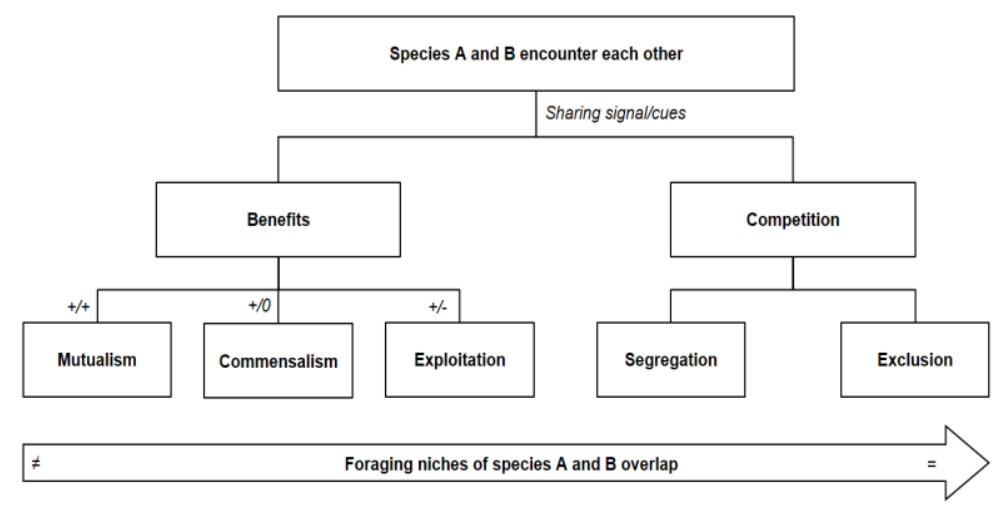

\section{Tables}

Table 1. Known examples of mixed-species groups in different arthropod taxa. The pairwise divergence time was obtained using the website timetree.org (estimated time). 


\begin{tabular}{|c|c|c|c|c|c|c|c|}
\hline & $\begin{array}{l}\text { ae spp., } \\
\text { Muscidae } \\
\text { spp. }\end{array}$ & & les & $\begin{array}{l}\text { salivary } \\
\text { enzymes } \\
\text { sharing, } \\
\text { heat } \\
\text { generatio } \\
\text { n, water } \\
\text { loss } \\
\text { limitation, } \\
\uparrow \text { survival } \\
\text { rate }\end{array}$ & $\begin{array}{l}\text { signal, } \\
\text { heat, } \\
\text { thigmotacti } \\
\text { sm }\end{array}$ & & $\begin{array}{l}\text { al., 1999; } \\
\text { Woodcock } \\
\text { et al., } \\
\text { 2002; } \\
\text { Gunn \& } \\
\text { Bird, } \\
2011 ; \\
\text { Boulay et } \\
\text { al., 2013, } \\
2016 \text { ) }\end{array}$ \\
\hline Chrysomelids & $\begin{array}{l}\text { Phratora } \\
\text { vitellinae, } \\
\text { Plagiodera } \\
\text { versicolora }\end{array}$ & $\begin{array}{l}\text { Same } \\
\text { taxa }\end{array}$ & $\begin{array}{l}\text { Juveni } \\
\text { les }\end{array}$ & $\begin{array}{l}\text { Protection } \\
\text { from } \\
\text { predators }\end{array}$ & $\begin{array}{l}\text { Chemical } \\
\text { cues }\end{array}$ & $\begin{array}{l}\text { Non- } \\
\text { social }\end{array}$ & $\begin{array}{l}\text { (Pasteels } \\
\& \\
\text { Gregoire, } \\
1984 \text { ) }\end{array}$ \\
\hline & $\begin{array}{l}\text { Nauphoeta } \\
\text { cinera, } \\
\text { Leucophaea } \\
\text { maderae }\end{array}$ & 105 & Adults & ??? & $\begin{array}{l}\text { Chemical } \\
\text { cues }\end{array}$ & $\begin{array}{l}\text { Two- } \\
\text { way }\end{array}$ & $\begin{array}{l}\text { (Everaerts } \\
\text { et al., } \\
1997)\end{array}$ \\
\hline C & $\begin{array}{l}\text { Orchesella } \\
\text { cincta, } \\
\text { O. villosa, } \\
\begin{array}{l}\text { Tomocerus } \\
\text { minor }\end{array}\end{array}$ & 284 & Adults & ??? & $\begin{array}{l}\text { Chemical } \\
\text { cues }\end{array}$ & $\begin{array}{l}\text { One- } \\
\text { way }\end{array}$ & $\begin{array}{l}\text { (Verhoef } \\
\text { et al., } \\
1977)\end{array}$ \\
\hline Crabs & $\begin{array}{l}\text { Pagurus } \\
\text { bernhardus, } \\
\text { P. prideauxi }\end{array}$ & $\begin{array}{l}\text { Same } \\
\text { taxa }\end{array}$ & $\begin{array}{l}\text { Adults } \\
\& \\
\text { Juveni } \\
\text { les }\end{array}$ & ??? & ??? & ??? & $\begin{array}{l}\text { (Meadows } \\
\text { \& Mitchell, } \\
1973 \text { ) }\end{array}$ \\
\hline Crustaceans & $\begin{array}{l}\text { Calappa } \\
\text { calappa, } \\
\text { Pachygraps } \\
\text { us } \\
\text { planifrons, } \\
\text { Lysiosquillin } \\
\text { a maculata, } \\
\text { L. sulcata, } \\
\text { Raoulserene } \\
\text { a sp., } \\
\text { Stenopus } \\
\text { hispidus, } \\
\text { Panulirus } \\
\text { penicillatus }\end{array}$ & 356 & $\begin{array}{l}\text { Juveni } \\
\text { les }\end{array}$ & $\begin{array}{l}\text { Habitat } \\
\text { selection }\end{array}$ & $\begin{array}{l}\text { Chemical } \\
\text { cues, } \\
\text { visual cues }\end{array}$ & $\begin{array}{l}\text { Two- } \\
\text { way }\end{array}$ & $\begin{array}{l}\text { (Lecchini } \\
\text { et al., } \\
2010)\end{array}$ \\
\hline
\end{tabular}

This article is protected by copyright. All rights reserved. 


\begin{tabular}{|c|c|c|c|c|c|c|c|}
\hline & $\begin{array}{l}\text { Panulirus } \\
\text { guttatus, } \\
\text { P. argus }\end{array}$ & $\begin{array}{l}\text { Same } \\
\text { taxa }\end{array}$ & Adults & $\begin{array}{l}\text { Recogniti } \\
\text { on of } \\
\text { alarm } \\
\text { odours, } \\
\text { shelter } \\
\text { sharing }\end{array}$ & $\begin{array}{l}\text { Chemical } \\
\text { cues }\end{array}$ & $\begin{array}{l}\text { Non- } \\
\text { social }\end{array}$ & $\begin{array}{l}\text { ( Lozano- } \\
\text { Álvarez \& } \\
\text { Briones- } \\
\text { Fourzán, } \\
\text { 2001; } \\
\text { Lozano- } \\
\text { Álvarez et } \\
\text { al., 2007; } \\
\text { Briones- } \\
\text { Fourzán } \\
\text { et al.., } \\
2008 \text { ) }\end{array}$ \\
\hline & $\begin{array}{l}\text { Alonella, } \\
\text { Ceriodaphni } \\
\text { a, Chydorus, } \\
\text { Megafenestr } \\
\text { a, Pleuroxus }\end{array}$ & $\begin{array}{l}\text { Same } \\
\text { taxa }\end{array}$ & Adults & $\begin{array}{l}\text { Protection } \\
\text { against } \\
\text { predators }\end{array}$ & $\begin{array}{l}\text { Similar } \\
\text { behaviour } \\
\text { or } \\
\text { pheromon } \\
\text { es emitted } \\
\text { by } \\
\text { Scapholeb } \\
\text { eris? }\end{array}$ & ??? & $\begin{array}{l}\text { (Kotov, } \\
2000)\end{array}$ \\
\hline Dermaptera & $\begin{array}{l}\text { Euborellia } \\
\text { moresta, } \\
\text { Forficula } \\
\text { auricularia, } \\
\text { F. decipiens, } \\
\text { F. } \\
\text { pubescens }\end{array}$ & 190 & $\begin{array}{l}\text { Adults } \\
\& \\
\text { Juveni } \\
\text { les }\end{array}$ & $\begin{array}{l}\text { Protection } \\
\text { from } \\
\text { predators }\end{array}$ & $\begin{array}{l}\text { Chemical } \\
\text { cues }\end{array}$ & $\begin{array}{l}\text { Two- } \\
\text { way? }\end{array}$ & $\begin{array}{l}\text { (Sauphan } \\
\text { or \& } \\
\text { Sureau, } \\
1993 \text { ) }\end{array}$ \\
\hline & $\begin{array}{l}40 \text { species } \\
\text { listed by } \\
\text { (Stanko et } \\
\text { al., 2002) }\end{array}$ & $\begin{array}{l}\text { Same } \\
\text { taxa }\end{array}$ & $\begin{array}{l}\text { Adults } \\
\& \\
\text { Juveni } \\
\text { les }\end{array}$ & $\begin{array}{l}\text { Suppressi } \\
\text { on of host } \\
\text { immune } \\
\text { system }\end{array}$ & $\begin{array}{l}\text { Reduction } \\
\text { of the size } \\
\text { of the } \\
\text { resource }\end{array}$ & $\begin{array}{l}\text { Non- } \\
\text { social }\end{array}$ & $\begin{array}{l}\text { (Krasnov } \\
\text { et al., } \\
2005, \\
2006 \text { ) }\end{array}$ \\
\hline & $\begin{array}{l}\text { Drosophila } \\
\text { sp. }\end{array}$ & $\begin{array}{l}\text { Same } \\
\text { taxa }\end{array}$ & $\begin{array}{l}\text { Adults } \\
\& \\
\text { Juveni } \\
\text { les }\end{array}$ & $\begin{array}{l}\text { Limit } \\
\text { fungal } \\
\text { growth }\end{array}$ & $\begin{array}{l}\text { Chemical } \\
\text { cues, egg- } \\
\text { batches, } \\
\text { non- } \\
\text { random } \\
\text { distribution } \\
\text { of } \\
\text { oviposition } \\
\text { sites }\end{array}$ & $\begin{array}{l}\text { Two- } \\
\text { way }\end{array}$ & $\begin{array}{l}\text { (Jaenike } \\
\text { \& James, } \\
\text { 1991; } \\
\text { Wertheim, } \\
\text { 2005; } \\
\text { Wertheim } \\
\text { et al., } \\
\text { 2006) }\end{array}$ \\
\hline Lady beetles & $\begin{array}{l}\text { Hippodamia } \\
\text { convergens, } \\
\text { H. } \\
\text { tredecimpun } \\
\text { ctata, } \\
\text { Hypera } \\
\text { postica }\end{array}$ & 239 & Adults & $\begin{array}{l}\downarrow \text { Mortality } \\
\text { during } \\
\text { winter, } \\
\text { protection } \\
\text { from } \\
\text { predators } \\
\text { and/or } \\
\text { parasitoid }\end{array}$ & $\begin{array}{l}\text { Presence } \\
\text { of aphid } \\
\text { prey, } \\
\text { environme } \\
\text { ntal stimuli } \\
\left(\mathrm{T}^{\circ}, \text { wind), }\right. \\
\text { chemical } \\
\text { cues }\end{array}$ & $\begin{array}{l}\text { Two- } \\
\text { way }\end{array}$ & $\begin{array}{l}\text { (Copp, } \\
\text { 1983; } \\
\text { Honek et } \\
\text { al., 2007; } \\
\text { Lee, } \\
\text { 1980; } \\
\text { Simpson } \\
\text { \& } \\
\text { Welborn, }\end{array}$ \\
\hline
\end{tabular}

This article is protected by copyright. All rights reserved. 


\begin{tabular}{|c|c|c|c|c|c|c|c|}
\hline & & & & s? & & & 1975) \\
\hline Loc & $\begin{array}{l}\text { Locusta } \\
\text { migratoria } \\
\text { migratorioid } \\
\text { es, } \\
\text { Schistocerca } \\
\text { gregaria }\end{array}$ & 81 & $\begin{array}{l}\text { Juveni } \\
\text { les }\end{array}$ & $\begin{array}{l}\text { Protection } \\
\text { from } \\
\text { predators }\end{array}$ & $\begin{array}{l}\text { Chemical } \\
\text { cues }\end{array}$ & $\begin{array}{l}\text { Two- } \\
\text { way }\end{array}$ & $\begin{array}{l}\text { (Niassy et } \\
\text { al., 1999; } \\
\text { Uvarov, } \\
1977 \text { ) }\end{array}$ \\
\hline M & $\begin{array}{l}\text { Eotetranych } \\
\text { us sp., } \\
\text { Tetranychus } \\
\text { urticae }\end{array}$ & $\begin{array}{l}\text { Same } \\
\text { taxa }\end{array}$ & $\begin{array}{l}\text { Juveni } \\
\text { les }\end{array}$ & $\begin{array}{l}\uparrow \text { Fertility, } \\
\uparrow \text { silk } \\
\text { production } \\
, \\
\uparrow \text { survival } \\
\text { rate }\end{array}$ & $\begin{array}{l}\text { Deposition } \\
\text { of faeces, } \\
\text { Intraguild } \\
\text { predation, } \\
\text { chemical } \\
\text { cues, silk } \\
\text { attraction } \\
\text { (sericophil } \\
\text { y) }\end{array}$ & $\begin{array}{l}\text { Non- } \\
\text { social }\end{array}$ & $\begin{array}{l}\text { (Le Goff, } \\
\text { 2011; } \\
\text { Slone, } \\
\text { 1999) }\end{array}$ \\
\hline Nitidulid beetles & $\begin{array}{l}\text { Carpophilus } \\
\text { dimidiatus, } \\
\text { C. freemani, } \\
\text { C. mutilatus, } \\
\text { C. antiquus, } \\
\text { C. } \\
\text { marginellus, } \\
\text { C. humeralis }\end{array}$ & $\begin{array}{l}\text { Same } \\
\text { taxa }\end{array}$ & Adults & ??? & $\begin{array}{l}\text { Chemical } \\
\text { cues }\end{array}$ & $\begin{array}{l}\text { One- } \\
\text { way }\end{array}$ & $\begin{array}{l}\text { (Bartelt et } \\
\text { al., 1993, } \\
1995)\end{array}$ \\
\hline & $\begin{array}{l}\text { Buthotus } \\
\text { judaicus, } \\
\text { Compsobuth } \\
\text { us werneri } \\
\text { judaicus, } \\
\text { Leiurus } \\
\text { quinquestriat } \\
\text { us }\end{array}$ & $\begin{array}{l}\text { Same } \\
\text { taxa }\end{array}$ & Adults & ??? & $\begin{array}{l}\text { Depends } \\
\text { on season, } \\
\text { specializati } \\
\text { on of } \\
\text { scorpions } \\
\text { for } \\
\text { different } \\
\text { prey, low } \\
\text { aggressive } \\
\text { ness }\end{array}$ & $\begin{array}{l}\text { Non- } \\
\text { social }\end{array}$ & $\begin{array}{l}\text { (Warburg, } \\
2000 \text { ) }\end{array}$ \\
\hline Spiders & $\begin{array}{l}\text { Hypochilus } \\
\text { thorelli, } \\
\text { Achaearane } \\
\text { a } \\
\text { tepidariorum }\end{array}$ & 308 & $\begin{array}{l}\text { Adults } \\
\& \\
\text { Juveni } \\
\text { les }\end{array}$ & $\begin{array}{l}\text { Web- } \\
\text { building, } \\
\text { web site } \\
\text { selection }\end{array}$ & $\begin{array}{l}\text { Chemical } \\
\text { cues, } \\
\text { vibrational } \\
\text { cues, silk } \\
\text { attraction } \\
\text { (sericophil } \\
\text { y) }\end{array}$ & $\begin{array}{l}\text { One- } \\
\text { way }\end{array}$ & $\begin{array}{l}\text { (Hodge \& } \\
\text { Storfer- } \\
\text { Isser, } \\
1997 \text { ) }\end{array}$ \\
\hline
\end{tabular}

This article is protected by copyright. All rights reserved. 


\begin{tabular}{|c|c|c|c|c|c|c|c|}
\hline & $\begin{array}{l}\text { Serracutiso } \\
\text { ma } \\
\text { proximum, } \\
\text { S. spelaeum }\end{array}$ & $\begin{array}{l}\text { Same } \\
\text { taxa }\end{array}$ & $\begin{array}{l}\text { Adults } \\
\& \\
\text { Juveni } \\
\text { les }\end{array}$ & $\begin{array}{l}\text { Protection } \\
\text { against } \\
\text { predators }\end{array}$ & $\begin{array}{l}\text { Chemical } \\
\text { cues? }\end{array}$ & $\begin{array}{l}\text { Two- } \\
\text { way }\end{array}$ & $\begin{array}{l}\text { (Chelini et } \\
\text { al., 2012) }\end{array}$ \\
\hline Stink bugs & $\begin{array}{l}\text { Nezara } \\
\text { viridula, } \\
\text { Chlorochroa } \\
\text { ligata, } \\
\text { C. sayi, } \\
\text { Thyanta } \\
\text { pallidovirens } \\
\text {, Euschistus } \\
\text { conspersus, } \\
\text { Eurydema } \\
\text { sp. }\end{array}$ & $\begin{array}{l}\text { Same } \\
\text { taxa }\end{array}$ & $\begin{array}{l}\text { Juveni } \\
\text { les }\end{array}$ & $\begin{array}{l}\text { Protection } \\
\text { against } \\
\text { desiccatio } \\
\mathrm{n} \text {, } \\
\text { developm } \\
\text { ental } \\
\text { accelerati } \\
\text { on, } \downarrow \\
\text { mortality, } \\
\downarrow \\
\text { predation } \\
\text { rates, } \\
\text { better } \\
\text { adherenc } \\
\text { e to } \\
\text { substrate }\end{array}$ & $\begin{array}{l}\text { Tactile } \\
\text { cues, } \\
\text { chemical } \\
\text { cues }\end{array}$ & $\begin{array}{l}\text { Two- } \\
\text { way }\end{array}$ & $\begin{array}{l}\text { (Fucarino } \\
\text { et al., } \\
2004 ; \\
\text { Ishiwatari, } \\
1976)\end{array}$ \\
\hline nid flour beetles & $\begin{array}{l}\text { Tribolium } \\
\text { castaneum, } \\
T . \\
\text { confusum, } \\
\text { T. freeman }\end{array}$ & $\begin{array}{l}\text { Same } \\
\text { taxa }\end{array}$ & Adults & $\begin{array}{l}\text { Attraction } \\
\text { of sexual } \\
\text { partners }\end{array}$ & $\begin{array}{l}\text { Chemical } \\
\text { cues }\end{array}$ & $\begin{array}{l}\text { Two- } \\
\text { way }\end{array}$ & $\begin{array}{l}\text { (Arnaud et } \\
\text { al., 2002; } \\
\text { Ryan \& } \\
\text { O'Ceallac } \\
\text { hain, } \\
1976 \text { ) }\end{array}$ \\
\hline 1) & $\begin{array}{l}\text { Reticuliterm } \\
\text { es } \\
\text { santonensis, } \\
\text { R. lucifugus } \\
\text { grassei }\end{array}$ & $\begin{array}{l}\text { Same } \\
\text { taxa }\end{array}$ & $\begin{array}{l}\text { Adults } \\
\& \\
\text { Juveni } \\
\text { les }\end{array}$ & ??? & $\begin{array}{l}\text { Chemical } \\
\text { cues }\end{array}$ & $\begin{array}{l}\text { Two- } \\
\text { way }\end{array}$ & $\begin{array}{l}\text { (Vauchot } \\
\text { et al., } \\
1996)\end{array}$ \\
\hline ch & $\begin{array}{l}\text { Haemaphys } \\
\text { alis } \\
\text { longicornis, } \\
\text { H. } \\
\text { megaspinos } \\
\text { a }\end{array}$ & $\begin{array}{l}\text { Same } \\
\text { taxa }\end{array}$ & $\begin{array}{l}\text { Juveni } \\
\text { les }\end{array}$ & $\begin{array}{l}\downarrow \text { Water } \\
\text { loss }\end{array}$ & $\begin{array}{l}\text { Chemical } \\
\text { cues }\end{array}$ & $\begin{array}{l}\text { Non- } \\
\text { social }\end{array}$ & $\begin{array}{l}\text { (Sonenshi } \\
\text { ne, 1985; } \\
\text { Tsunoda, } \\
\text { 2007) }\end{array}$ \\
\hline Treehoppers & $\begin{array}{l}\text { Aconophora } \\
\text { nitida, } \\
\text { A. mexicana }\end{array}$ & $\begin{array}{l}\text { Same } \\
\text { taxa }\end{array}$ & $\begin{array}{l}\text { Juveni } \\
\text { les }\end{array}$ & $\begin{array}{l}\text { Protection } \\
\text { from } \\
\text { predators, } \\
\text { maternal } \\
\text { care }\end{array}$ & $\begin{array}{l}\text { Stochastic } \\
\text { phenomen } \\
\text { on or } \\
\text { shared } \\
\text { oviposition } \\
\text { sites by } \\
\text { females }\end{array}$ & $\begin{array}{l}\text { Non- } \\
\text { social }\end{array}$ & $\begin{array}{l}\text { (Olmstead } \\
\text { \& Wood, } \\
\text { 1990; } \\
\text { Wood, } \\
1979 \text { ) }\end{array}$ \\
\hline
\end{tabular}

This article is protected by copyright. All rights reserved. 


\begin{tabular}{|c|c|c|c|c|c|c|c|}
\hline Triatomine bugs & 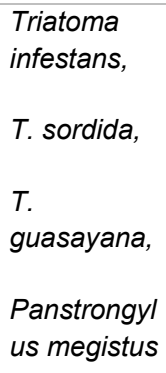 & 36 & $\begin{array}{l}\text { Adults } \\
\text { \& } \\
\text { Juveni } \\
\text { les }\end{array}$ & $\begin{array}{l}\text { Better } \\
\text { exploitatio } \\
\mathrm{n} \text { of } \\
\text { protected } \\
\text { places }\end{array}$ & $\begin{array}{l}\text { Chemical } \\
\text { cues, } \\
\text { faeces }\end{array}$ & $\begin{array}{l}\text { Two- } \\
\text { way }\end{array}$ & $\begin{array}{l}\text { (Lorenzo } \\
\text { \& Lazzari, } \\
\text { 1998; } \\
\text { Mota \& } \\
\text { Lorenzo, } \\
\text { 2012) }\end{array}$ \\
\hline & $\begin{array}{l}\text { Ampyx, } \\
\text { Asaphellus }\end{array}$ & $\mathrm{N} / \mathrm{A}$ & Adults & ??? & ??? & ??? & $\begin{array}{l}\text { (Chatterto } \\
\text { n \& } \\
\text { Fortey, } \\
2008 \text { ) }\end{array}$ \\
\hline etles & $\begin{array}{l}\text { Gyrinidae } \\
\text { sp. }\end{array}$ & $\begin{array}{l}\text { Same } \\
\text { taxa }\end{array}$ & Adults & $\begin{array}{l}\text { Predator } \\
\text { avoidance } \\
\text {, } \\
\uparrow \\
\text { defensive } \\
\text { secretion }\end{array}$ & $\begin{array}{l}\text { Mechanica } \\
\text { I stimuli } \\
\text { (water } \\
\text { waves), } \\
\text { chemical } \\
\text { cues } \\
\text { (pygidial } \\
\text { secretion?) } \\
\text {, visual } \\
\text { cues, } \\
\text { orientation } \\
\text { to } \\
\text { neighbours }\end{array}$ & $\begin{array}{l}\text { Two- } \\
\text { way }\end{array}$ & $\begin{array}{l}\text { (Heinrich } \\
\text { \& Vogt, } \\
\text { 1980; } \\
\text { Vulinec \& } \\
\text { Miller, } \\
1989 \text { ) }\end{array}$ \\
\hline & $\begin{array}{l}\text { Porcellio } \\
\text { scaber, } \\
\text { Armadillidiu } \\
m \text { vulgare, } \\
\text { Oniscus } \\
\text { asellus }\end{array}$ & 161 & Adults & $\begin{array}{l}\text { Protection } \\
\text { from } \\
\text { desiccatio } \\
\mathrm{n}, \\
\uparrow \\
\text { production } \\
\text { of faeces } \\
\text { (secondar } \\
\text { y food } \\
\text { source) }\end{array}$ & $\begin{array}{l}\text { Tactile } \\
\text { cues, } \\
\text { chemical } \\
\text { cues }\end{array}$ & $\begin{array}{l}\text { Two- } \\
\text { way }\end{array}$ & $\begin{array}{l}\text { (Broly et } \\
\text { al., 2016; } \\
\text { Yoder et } \\
\text { al., 2005)) }\end{array}$ \\
\hline
\end{tabular}

N/A: Not Available; $\uparrow:$ increase; $\downarrow$ : decrease; ???: unknown.

This article is protected by copyright. All rights reserved. 